\title{
Investigating the impact of land-use land-cover change on Indian summer monsoon daily rainfall and temperature during 1951-2005 using a regional climate model
}

\section{S. Halder et al.}

Correspondence to: S. Halder (shalder3@gmu.edu)

The copyright of individual parts of the supplement might differ from the CC-BY 3.0 licence. 


\section{Method of preparation of LULC}

Present day natural PFT distribution and its matching LAI values for CLM are prepared based on the methodology of Lawrence et al. 2007. Fractions of bare ground and forest cover are derived from the Moderate Resolution Imaging Spectroradiometer (MODIS) data (Hansen et al. 2003). Trees are differentiated into broadleaf/needleleaf and evergreen/deciduous types using the Advanced Very High Resolution Radiometer (AVHRR) tree cover data (DeFries et al. 2000). Herbaceous grasses, shrubs and crops constitute the remaining grid cell area. Global cropland area data for year 2000 from Ramankutty et al. (2008) and herbaceous grasses and shrubs from MODIS (Friedl et al. 2002) constitute the remaining grid cell area. Trees, grasses and shrubs were then classified into PFTs of tropical, temperate and boreal type using the physiology and climate rules of Nemani and Running (1996), and C3/C4 photosynthetic pathways based on MODIS derived LAIs and the mapping methods of Still et al. (2003). Understory grasses were not considered. Finally, the crop area in a grid cell was adjusted using the UNH dataset for year 200, and non-tree PFTs were modified to accommodate any displaced area. Preparation of CLM potential vegetation PFT distribution for the historical period when the human activities associated with present climatic condition may be assumed to have been less is based on Lawrence and Chase (2010). Present day PFT composition of remnant natural biomes based on Ramankutty et al. 2008) are used for spatial extrapolation to potential PFT biome distributions given by Ramankutty et al. (2008) using inverse distance weighting methods. Remnant natural PFT parameters of present day were taken from Lawrence and Chase (2007) to maintain consistency between the two datasets. 
Thereafter, a time series of annual global LULC is prepared by adjusting the global present and potential PFT distributions using the UNH data. At first, if the available land area in a grid cell, which is the net area other than glacier, wetlands, lake and urban area, is less than the UNH crop area then it is assigned to the crop PFT. Pastures which represent grazing in UNH data, are then assigned using the present day proportion of grasses (i.e. C3, C4 and boreal C3 PFTs) and shrubs compared to bare soil. The grazing area is set to the larger of the potential or present day total vegetated PFT area if it exceeds any of those, in order to exclude sparsely grazed regions. However, if the grazing area is less than or equal to those, it is assigned to $\mathrm{C} 3$ or $\mathrm{C} 4$ grasses based on their potential or present day PFT fractions. In other areas where present day or potential vegetation grass PFT fractions are insufficient, present day tree PFTs are replaced with grass, followed by shrub PFTs. After crops and pastures, the land area in a grid cell is considered for primary or undisturbed natural vegetation based on the UNH data, and uses the potential vegetation PFT distribution. By prescribing present day non-crop and non-pasture PFTs to the remaining land area, secondary natural vegetation is assigned. Therefore, the resulting annual PFT distributions are not only consistent with CLM parameters for present day and potential vegetation but also with the vegetation areas of UNH. Details about the methodology, consideration of wood harvest and uncertainties may be found in the Technical Note on CLMv4.0 by Oleson et al. 2010. This LULC dataset does not have the urban area category, and we do not intend to include its effects in our simulations. 


\section{References}

DeFries, R.S., Hansen, M.C., Townshend, J.R.G., Janetos, A.C., and Loveland, T.R.: A new global $1-\mathrm{km}$ dataset of percentage tree cover derived from remote sensing, Glob. Change Biol. ,6, 247-254, 2000.

Friedl, M.A., McIver, D.K., Hodges, J.C.F., Zhang, X.Y., Muchoney, D., Strahler, A.H., Woodcock, C.E., Gopal, S., Schneider, A., Cooper, A., Baccini, A., Gao, F., and Schaaf, C.: Global land cover mapping from MODIS: algorithms and early results, Remote Sens. Environ., 83, 287-302, 2002.

Hansen, M., DeFries, R.S., Townshend, J.R.G., Carroll, M., Dimiceli, C., and Sohlberg R.A.: Global Percent Tree Cover at a Spatial Resolution of 500 meters: First Results of the MODIS Vegetation Continuous Fields Algorithm, Earth Interact., 7, 10, 1-15, doi: http://dx.doi.org/10.1175/1087-3562(2003)007<0001:GPTCAA>2.0.CO;2, 2005.

Lawrence, P.J., and Chase, T.N.: Representing a new MODIS consistent land surface in the Community Land Model (CLM 3.0), J Geophys Res 112:G01,023, doi:10.1029/2006JG000,168, 1-17, 2007.

Lawrence, P.J., and Chase, T.N.: Investigating the climate impacts of global land cover change in the community climate system model, Int. J. Climatol., 30, doi: 10.1002/joc.2061, 20662087, 2010.

Nemani, R.R., and Running, S.W: Implementation of a hierarchical global vegetation classification in ecosystem function models, J. Veg. Sci. 7, 3, 337-346, 1996.

Oleson, K.W., Lawrence, D.M., Bonan, G.B., Flanner, M.G., Kluzek, E., Lawrence, P.J., Levis, S., Swenson, S.C., Thornton, P.E., Dai, A., Decker, M., Dickinson, R., Feddema, J., Heald, C.L., Hoffman, F., Lamarque, J.F., Mahowald, N., Niu, G.Y., Qian, T., Randerson, J., Running, S., Sakaguchi, K., Slater, A., Stockli, R., Wang, A., Yang, Z.L., Zeng, X., and Zeng, X.: Technical description of version 4.0 of the Community Land Model (CLM), NCAR Technical Note NCAR/TN-387+STR, NCAR, pp.257, 2010.

Ramankutty, N., Evan, A.T., Monfreda, C., and Foley, J.A.: Farming the planet: 1. Geographic distribution of global agricultural lands in the year 2000, Global Biogeochem. Cy., 22, GB1003, doi:10.1029/2007GB002,952, 1-19, 2008.

Still, C.J., Berry, J.A., Collatz, G.J., and DeFries, R.S.: Global distribution of C3 and C4 vegetation: Carbon cycle implications, Global Biogeochem. Cy.,17, doi: 10.1029/2001GB001807, 2003. 
a)

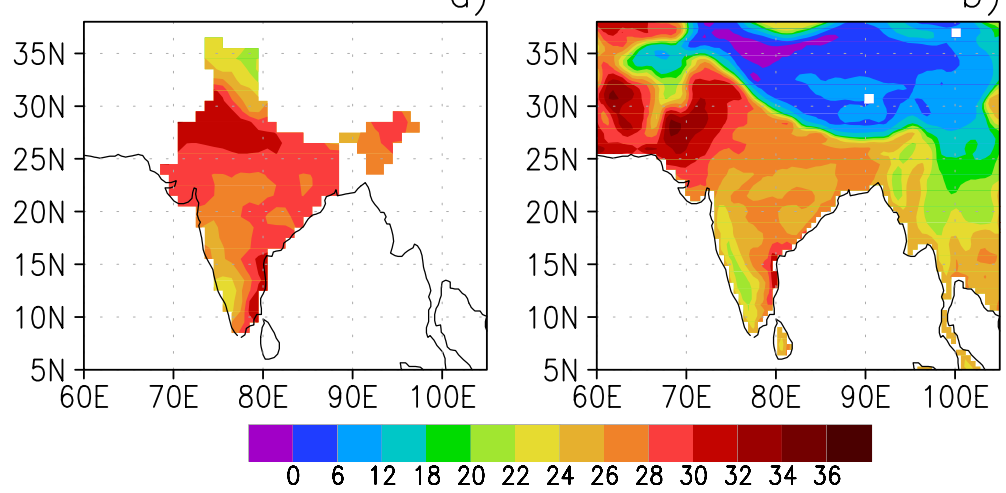

b)

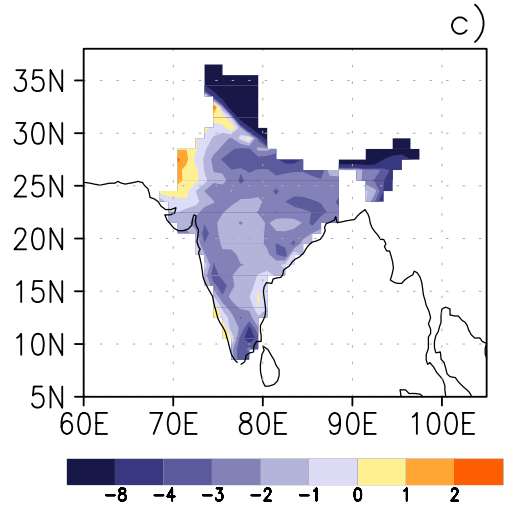

Supplementary Figure S1. Seasonal (JJAS) averaged $2 \mathrm{~m}$ air temperature (in ${ }^{\circ} \mathrm{C}, 1982-$ 2005) a) in IMD data, b) in PLC experiment, c) difference (b-a).

a)

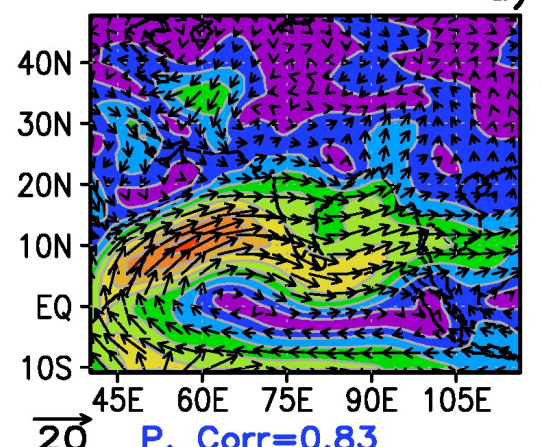

b)

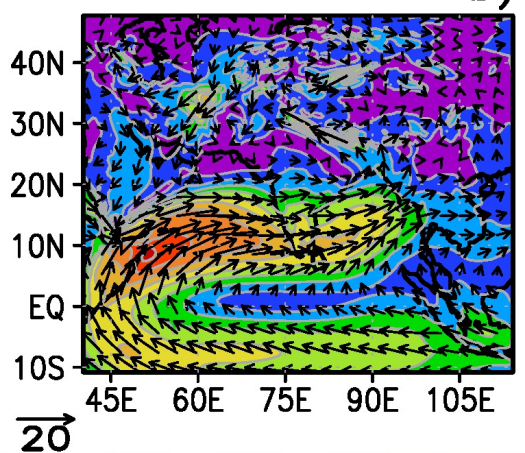

c)

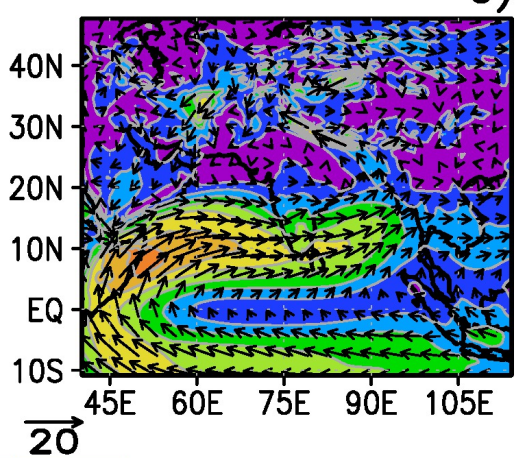

d)

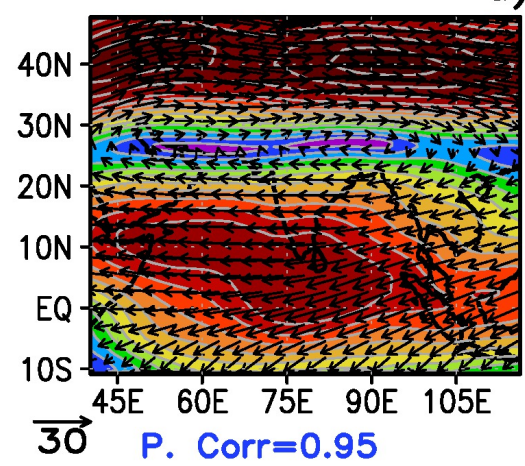

e)

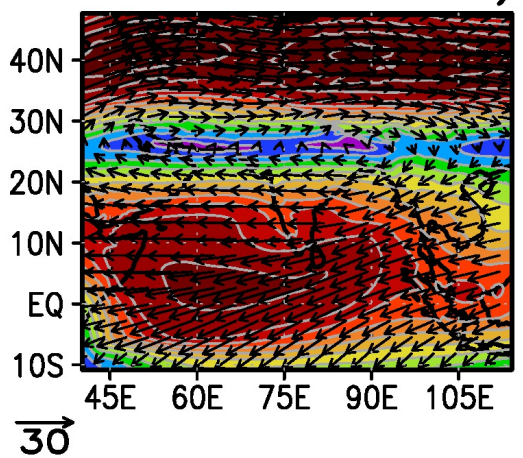

f)

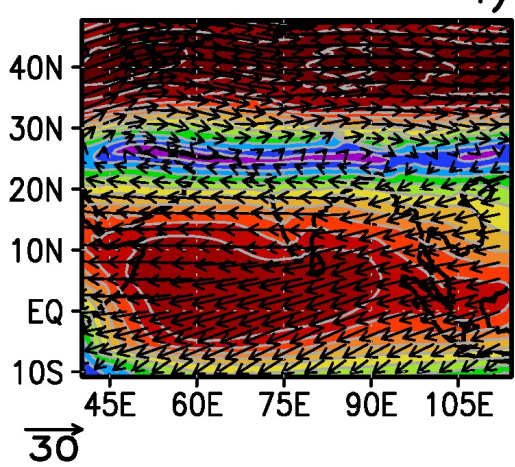

Supplementary Figure S2. Seasonal (JJAS) averaged wind (in $\mathrm{m} \mathrm{s}^{-1}, 1982-2008$ ) at 850 $\mathrm{hPa}$ level a) in NCEP reanalysis, b) in PLC experiment c) in PLCS experiment. Seasonal (JJAS) averaged wind (in $\mathrm{m} \mathrm{s}^{-1}, 1982-2008$ ) at 200hPa level a) in NCEP reanalysis, b) in PLC experiment $\mathrm{c}$ ) in PLCS experiment. The shaded color depicts magnitude and arrows show the direction. 